\title{
30 anos de RPMGF como organização aprendente
}

Paula Broeiro*

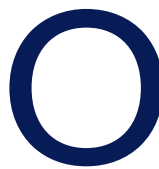

processo de mudança do corpo editorial da Revista Portuguesa de Medicina Geral e Familiar (RPMGF) em curso decorre como esperado numa organização inteligente, em que a equipa que inicia aprende com as virtudes e os insucessos do passado, numa espiral evolutiva. Este processo de transição fez-nos refletir no quanto tem sido um exemplo de sucesso a organização RPMGF, acompanhando a evolução do conhecimento médico e adaptando-se ao progresso tecnológico.

A RPMGF tem sido um instrumento técnico, transversal às sucessivas Direções da APMGF, sensíveis à sua importância e a sua história fará justiça à da Medicina Geral e Familiar (MGF) em Portugal. A RPMGF, ${ }^{1}$ designada Revista Portuguesa de Clínica Geral (RPCG) até 2011, nem sempre foi como a conhecemos, com um Diretor e um corpo editorial. Lembrar-se-ão, os mentores da revista nos seus primórdios, das edições manuais de corte e cola e dos arcaicos computadores, bem diferente do que é hoje o nosso presente, em que dispomos de um fórum e de um gestor de artigos e prestes a ter um processo de submissão em linha, através da plataforma Open Journal System! Este progresso teve sempre equipas de obreiros anónimos que, voluntariamente, aceitaram essa missão. Aproveitando a mudança da equipa editorial, coincidente com os seus 30 anos de existência, faremos um balanço histórico.

A primeira diretora foi a Dr. ${ }^{a}$ Madalena Mourão, em 1984, seguindo-se o Dr. Mário Moura, que exerceu esta função até 1999, beneficiando de ilustres diretores adjuntos, como o Dr. Vítor Ramos e o Prof. Doutor Armando Brito de Sá e de editores, como os Drs. Eduardo Mendes e José António Miranda.

A partir de 2000, a organização da então RPCG passou a ter uma estrutura semelhante à atual, tendo sido o Prof. Doutor Vasco Maria o primeiro diretor desta segunda fase. De seguida, os diretores Prof. Doutor Ar-

*Directora da Revista Portuguesa de Medicina Geral e Familiar mando Brito de Sá, o Prof. Doutor Jaime Correia de Sousa, o Dr. António Faria Vaz e, por último, a Dr. ${ }^{a}$ Raquel Braga. Cada um trouxe uma energia muito pessoal que, com uma equipa dinâmica, impulsionou visivelmente a revista. Lendo o primeiro e último editoriais de cada um dos diretores, percebe-se o entusiasmo inicial, o sentido de missão, o reconhecimento do dever cumprido e a consciência grata de se ter enriquecido nesse trabalho coletivo. Mas quem verdadeiramente ganhou foi a Medicina Geral e Familiar. Obrigada!

Num exercício reflexivo de pensar o futuro sobre o sucesso do passado, lemos o papel de cada equipa editorial como o de atletas olímpicos que, transportando a tocha à medida que o tempo passa, avançam e chegam mais longe e mais alto, por terem ganho o caminho já percorrido pelos antecessores! Como todos os percursos, nem sempre fáceis, as sucessivas «resilientes equipas» ultrapassaram as tortuosidades do caminho traçado, encontrando-se a RPMGF prestes a chegar ao destino almejado: a consolidação de indexação à MEDLINE. Percurso iniciado pela equipa liderada pelo Prof. Doutor Jaime Correia de Sousa e reiniciado pela equipa da Dr. ${ }^{a}$ Raquel Braga. Entre as duas submissões de indexação à MEDLINE, a equipa do Dr. Faria Vaz, em 2009, conseguiu o primeiro passo para a expansão internacional, com a indexação à plataforma latino-americana SciELO. ${ }^{2}$

O que tem caracterizado o sucesso da revista, talvez seja o seu perfil de organização aprendente. À luz dos conceitos subjacentes a uma organização aprendente, refletimos o passado da RPMGF, alicerçado no qual se tem construído o futuro.

Organizações aprendentes são aquelas onde as pessoas desenvolvem continuamente a sua criatividade, novas ideias são alimentadas, a aspiração coletiva é libertada e as pessoas aprendem continuamente umas com as outras. ${ }^{3}$ A ideia não é inovadora, encontra-se presente na ideia de coletividade-como-indivíduo-imortal, de Almada Negreiros: «A colectividade é tam- 
bém um indivíduo, um indivíduo como qualquer outro, mas é o indivíduo colectivo, na verdade colectivo e indivíduo. Com a vantagem sobre qualquer outro de não estar sujeito, como nós, às vacilações de um organismo mortal.»

À medida que o mundo se torna mais globalizado, as organizações tornam-se mais complexas e dinâmicas, devendo o trabalho ser mais aprendente. As organizações com futuro são as que descobrem como desenvolver a capacidade de aprender das pessoas. As organizações que aprendem são constituídas por pessoas, em que os objetivos comuns se sobrepõem aos individuais. Funcionam em conjunto, com confiança mútua, complementando-se nos pontos fortes e compensando-se nas limitações. ${ }^{3}$

A RPMGF, enquanto organização aprendente, terá beneficiado de: lideranças com inteligência emocional capazes de construir equipas comprometidas com o sucesso da organização e com a aprendizagem ao longo da vida?; uma estrutura e pensamento sistémico vinculados pelo tecido invisível das interações pessoais, em que cada um potencia o todo?; de equipas reflexivas capazes de expor o seu pensamento e abertas à influência de outros?; de grandeza de ideias e criatividade compartilhadas, criando uma identidade e sentido de destino comum?; de "diálogo», como a capacidade de cada um suspender suposições pessoais e aderir a um verdadeiro pensar em conjunto?

Sim. Seguramente que sim. Ser uma organização aprendente contribuiu para o sucesso da RPMGF. Terão ainda contribuído a personalidade dos seus líderes, a diversidade das equipas, a sua renovação cíclica e, com certeza, cada equipa invisível, teve estrutura e pensamento sistémicos, com pessoas capazes de interagir, potenciando-se e um verdadeiro pensar conjunto.

A RPMGF, 30 anos depois, consegue uma interação única com os seus leitores em que o conhecimento expressado tem reflexo na prática e é a prática que gera o conhecimento publicado, numa espiral reflexiva de conhecimento. ${ }^{4-5}$ Como foi desejo expresso no primeiro editorial, a RPMGF não envelheceu precocemente e foi adquirindo maturidade, sendo o eco do trabalho e da colaboração de todos os médicos de família. ${ }^{6}$

Conseguiu, pois, transpor as características de organização aprendente para a comunidade alargada dos seus revisores, autores e leitores, refletindo a excelência do ser Médico de Família.

\section{REFERÊNCIAS BIBLIOGRÁFICAS}

1. Braga R. Um outro nome para uma realidade em mudança. Rev Port Clin Geral. 2011;27(6):495-6.

2. Faria-Vaz A. O conhecimento, enquanto cultura e motivação. Rev Port Clin Geral. 2009;25(6):624-5.

3. Senge $P$. The fifth discipline: the art \& practice of the learning organization. New York, NY: Currency Doubleday; 1990.

4. Agostinho-Santos J.A RPMGF e os seus leitores colaterais. Rev Port Clin Geral. 2014;30(1):51-2.

5. Horsley T, Grimshaw J, Campbell C. How to create conditions for adapting physicians' skills to new needs and lifelong learning. Copenhagen: World Health Organization; 2010. Available from: http://www.euro.who. int/_data/assets/pdf_file/0020/124418/e94294.pdf

6. Mourão M. Editorial. Rev Port Clin Geral. 1984;1:3.

\section{ENDEREÇO PARA CORRESPONDÊNCIA}

director@rpcg.apmcg.pt 